\title{
AKSESBILITAS PENYANDANG DISABILITAS DALAM PELAYANAN PUBLIK DI KABUPATEN TEGAL
}

\author{
Sesya Dias Mumpuni ${ }^{1}$, Arif Zainudin ${ }^{2}$ \\ Program Studi Bimbingan dan Konseling ${ }^{1}$, Program Studi Ilmu Pemerintahan ${ }^{2}$ \\ Universitas Pancasakti Tegal ${ }^{1,2}$ \\ Email: dias.mumpuni@gmail.com ${ }^{1}$, arif_zainudin88@yahoo.com²
}

\begin{abstract}
Abstrak
Sebagian besar penyandang disabilitas mampu untuk mengelola diri dalam hidupnya. Kemampuan yang dimiliki oleh kaum disabilitas ini sangat bertolak belakang dengan penyediaan fasilitas atau kebijakan yang diberikan untuk pelayanan kaum disabilitas. Banyak ditemui bahwa unit pelayanan yang diberikan oleh pemerintah tidak mendukung akses pelayanana kamu disabilitas. Oleh karena itu penting dilakukan kajian tentang aksesbilitas pelayanan publik yang dikhususkan untuk difabel. Maka dibutuhkan pemahaman khusus bagi peneliti untuk mengkaji apa yang dirasakan difabel. Hal ini merupakan substansi dari konseling lintas budaya yang selama ini menjadi hal yang tabu jika membahas kaum difabel.

Penelitian ini bertujuan untuk mengetahui hubungan antara aksesibilitas difabel dengan ketersediaan layanan publik di Kabupaten Tegal. Kemudian melihat Faktor apa saja yang menyebabkan tidak terpenuhinya aksesibilitas bagi difabel di Kabupaten Tegal. Metode yang akan dipakai dalam pencapaian tujuan adalah kualitatif. Dalam pengambilan sampel random maka dari populasi 'semua penyandang disabilitas di Kabupaten Tegal' diambil sampelnya yaitu kategori difabel laki-laki, perempuan, kusta dan psikososial yang berjumlah 30 orang. Pengguanaan data secara kualitatif diharapkan dapat mendalam dan mengena pada aspek yang jarang diketahui oleh kebanyakan orang. Analisis data mengguanakan triangulasi data yang didapat dari hasil observasi, wawancara dan kajian dokumen.
\end{abstract}

Kata Kunci: difabel, fasilitas publik, pendidikan masyarakat

\section{DISABILITY ACCESSIBILITY IN PUBLIC SERVICE IN TEGAL REGENCY}

\author{
Sesya Dias Mumpuni, Arif Zainudin \\ Departement of Guidance and Counseling, Departement of Goverment Science \\ Universitas Pancasakti Tegal \\ Email: dias.mumpuni@gmail.com danarif_zainudin88@yahoo.com
}

\begin{abstract}
Most people with disabilities are able to manage themselves in their lives. The ability of these disabilities is in stark contrast to the provision of facilities or policies provided for disability ministry. Many find that the service units provided by governments do not support your access to disabilities. It is therefore important to review the accessibility of public services devoted to disabilities. This is the substance of cross-cultural counseling which has been a taboo when discussing the disabilities.

This study aims to determine the relationship between accessibility of the disabled with the availability of public services in Tegal regency. Then see what factors are causing accessibility accessibility for disable in Tegal regency. The method to be used in the achievement of goals is qualitative. In the random sampling, the population of 'all persons with disabilities in Kabupaten Tegal' is taken the sample which is male, female, leprosy and psychosocial category with 30 people. Qualitative data processing is expected to be deep and appealing to aspects that are rarely known by most people. Data analysis used triangulation of data obtained from the observation, interview and document review.
\end{abstract}

Keywords: difable, public facility, community education 


\section{PENDAHULUAN}

Disabilitas merupakan isu kompleks pada semua lapisan masyarakat. Disabilitas mencakup orang-orang dengan kekurangan fisik maupun psikis yang ada dalam masyarakat. Maka penyebutan orang-orang disabilitas dapat lebih familiar dengan menyebut dengan difabel. Dengan adanya predikat difabel, maka masyarakat dengan mudahnya membagi strata sosialnya dengan diri 'orang normal' dibandingkan dengan 'orang cacat/difabel'.

Menurut Pasal 1 ayat 1 Undang-undang Nomor 4 Tahun 1997 tentang Penyandang Cacat menjelaskan bahwa "Penyandang cacat adalah setiap orang yang mempunyai kelainan fisik dan/atau mental, yang dapat mengganggu atau merupakan rintangan dan hambatan baginya untuk melakukan kegiatan secara layaknya, yang terdiri dari penyandang cacat fisik, penyandang cacat mental, penyandang cacat fisik dan mental."

Dengan penyebutan seperti itu maka sudah ada diskriminasi yang kuat pada susunan masyarakat kita. Maka tidak heran difabel yang ada dalam masyarakat kita menarik diri dalam partisipasi di masyarakat. Misalnya pada penyebutan orang berkursi roda, tangan palsu, orang gila dan sebagainya. Adanya label predikat tersebut maka sulit bagi difabel untuk ikut berbaur dan berpartisipasi dalam kegiatan masyarakat. Pasti dalam diri difabel ada perasaan yang berpengaruh pada aktifitas kehidupannya. Bahkan banyak difabel yang hidup dalam keluarga dan komunitas masyarakat yang belum memahami atau ikut mendukung diri difabel tanpa adanya diskriminasi dan prasangka.

Pemahaman diri difabel akan adanya pemenuhan kebutuhan dirinya tidak akan dapat terwujud tanpa adanya dukungan penuh dari orang-orang di sekitarnya. Pemahaman diri tercermin dari partisipasi difabel dalam segala aspek kehidupan bermasyarakat. Partisipasi difabel dalam pelayanan publik menjadi prioritas yang wajib bagi keberadaan difabel. Hal ini merupakan kesetaraan bagi setiap manusia untuk memenuhi kebutuhan dalam hidupnya. Difabel menggunakan fasilitas umum sama dengan manusia pada umumnya. Maka perlu adanya ketersediaan sarana dan prasarana yang mampu menunjang difabel untuk mengakses layanan publik. Menurut Pasal 1 ayat 4 Undangundang Nomor 4 Tahun 1997 tentang Peyandang Cacat meyebutkan bahwa Aksesibilitas merupakan kemudahan yang disediakan bagi penyandang cacat guna mewujudkan kesamaan kesempatan dalam segala aspek kehidupan dan penghidupan.

Kesadaran diri difabel tidak lepas dari kekuatan dalam diri difabel untuk terus dapat berpartisipasi dalam aktifitas masyarakat. Dengan adanya partisipasi tersebut, maka pandangan orang-orang terhadap difabel dapat lebih baik. Mereka dapat memahami keberadaan difabel dan dapat menempatkan posisi dirinya saat 
bersama difabel. Untuk menghilangkan diskriminasi dan prasangka memang tidak mudah, maka perlu peran serta dari semua pihak untuk dapat mendukung partisipasi difabel dalam bermasyarakat.

Orang-orang difabel yang berada dalam lingkungan masyarakat memiliki sudut pandang yang berbeda. Masyarakat yang pada umumnya terdiri dari manusia normal memiliki kelengkapan tubuh yang berbeda dengan difabel. Semua sarana umum yang ada dalam ranah publik hanya diperuntukkan untuk orang-orang normal saja. Hal ini yang membuat difabel merasa kesulitan untuk mengakses fasilitas yang ada disekitar mereka. Bahkan fasilitas yang ada tidak ada bagi para difabel. Orang lain yang normal menganggap difabel tidak produktif yang tidak dapat menjalankan kewajibannya dengan baik. Sehingga hak-haknya pun diabaikan. Karena kurang adanya kesetaraan hak asasi manusia khsusunya pada difabel maka perlu adanya evaluasi dari pihak pemerintah.

Pemerintah hanya menyediakan pusat rehabilitasi bagi difabel. Padahal difabel yang ada di masyarakat sangat banyak dan tidak dapat tertampung semua dalam pusat rehabilitasi. Istilah pusat rehabilitasi juga merujuk kepada difabel bahwa mereka berbeda dengan manusia normal. Difabel bukan penyakit kronis yang disamakan dengan pusat rehabilitasi narkoba dan anak jalanan bahkan. Penyebutan bagi tempat difabel untuk berkumpul dalam satu komunitas kurang tepat. Hal tersebut membuat kesenjangan yang semakin besar dibuat oleh lembaga sendiri yang notabene harus memenuhi hak semua warga negara.

Difabel menggunakan fasilitas umum sama dengan manusia normal yang lain. Maka perlu adanya ketersediaan sarana dan prasarana yang mampu menunjang difabel untuk mengakses layanan tersebut. Di Kabupaten Tegal terdapat data statistik jumlah difabel yang terdiri dari laki-laki dan perempuan. Jumlah yang ada di Kabupaten Tegal tergolong banyak yaitu total 4.351 difebel. Padahal dalam kriteria difabel juga ada eks penyandang kusta, tetapi data yang diperoleh tidak menunjukkan adanya difabel eks penyandang kusta.

Memberikan pemahaman kepada masyarakat khususnya difabel mengenai pentingnya aksesbilitas penyandang disabilitas dalam pelayanan publik di Kabupaten Tegal. Memberikan deskripsi gambaran aksesbilitas penyandang disabilitas dalam pelayanan publik di Kabupaten Tegal dalam lima bidang layanan publik karena pada bidang tersebut merupakan hal yang dilakukan difabel sehari-hari. Pemenuhan hak difabel yang ada di Indonesia khususnya Kabupaten Tegal ternyata belum sepenuhnya optimal. Dalam Australian Aid: Indonesia Infrastructure Initiative (2016) menyebutkan:

"Pemerintah Indonesia telah membuat kebijakan Undang-undang Nomor 4 Tahun 2007 tentang Penyandang Disabilitas, Undang-undang Nomor 23 Tahun 2007 tentang Perkeretaapian dan 
Undang-undang Nomor 22 Tahun 2009 tentang Lalu Lintas dan Angkutan Jalan, dan peraturan-peraturan untuk memastikan bahwa para penyandang disabilitas memiliki kesempatan dan akses yang sama terhadap fasilitas seperti orang lain."
Data yang diperoleh dari tegalkab.bps.go.id memperlihatkan bahwa penyandang disabilitas di Kabupaten Tegal seperti yang ada pada tebel di bawah ini.

Tabel 1.1 Data BPS Kabupaten Tegal tahun 2014

\begin{tabular}{|c|c|c|c|c|c|}
\hline \multirow{2}{*}{ No } & \multirow{2}{*}{$\frac{\text { Jenis PMKS dan PSKS }}{\text { PMKS }}$} & \multicolumn{2}{|c|}{ Populasi } & \multicolumn{2}{|c|}{ Dilayani } \\
\hline & & $\mathrm{L}$ & $\mathrm{P}$ & $\mathrm{L}$ & $\mathrm{P}$ \\
\hline 1 & Anak Balita Terlantar & 41 & 44 & - & - \\
\hline 2 & Anak Terlantar & 196 & 160 & - & - \\
\hline 3 & $\begin{array}{l}\text { Anak yang menjadi korban tindak kekerasan/ } \\
\text { diperlakukan salah }\end{array}$ & 21 & 65 & - & - \\
\hline 4 & Anak Nakal & - & - & - & - \\
\hline 5 & Anak Jalanan & 21 & 2 & - & - \\
\hline 6 & Anak Cacat & 806 & 648 & - & - \\
\hline 7 & Wanita Rawan Sosial Ekonomi & - & 5 & - & 150 \\
\hline 8 & $\begin{array}{l}\text { Wanita yang menjadi korban tindak kekerasan/ } \\
\text { diperlakukan salah }\end{array}$ & - & 37 & - & - \\
\hline 9 & Lanjut Usia Terlantar & 988 & 2 & - & - \\
\hline 10 & $\begin{array}{l}\text { Lanjut Usia yang menjadi korban tindak kekerasan/ } \\
\text { diperlakukan salah }\end{array}$ & - & - & - & - \\
\hline \multirow[t]{7}{*}{11} & Penyandang Cacat & - & - & - & - \\
\hline & Cacat Tubuh & 755 & 461 & - & - \\
\hline & Cacat Mata (tuna netra) & 382 & 435 & - & - \\
\hline & Tuna rungu/ wicara & 349 & 298 & - & - \\
\hline & Cacat eks psikotik & 483 & 285 & - & - \\
\hline & Cacat mental retardasi & 368 & 231 & - & - \\
\hline & Cacat fisik \& mental & 153 & 151 & - & - \\
\hline \multirow[t]{3}{*}{12} & Penyandang Cacat Bekas Penyandang Penyakit Kronis & - & - & - & - \\
\hline & Non kusta & - & - & - & - \\
\hline & Eks kusta & - & - & - & - \\
\hline 13 & Penyandang HIV/AIDS & 2 & 2 & - & - \\
\hline 14 & Tuna susila & - & 325 & - & 100 \\
\hline 15 & Pengemis & 133 & 124 & - & - \\
\hline
\end{tabular}

Aksesibiltas bagi difabel diutamakan dalam hal ketersediaan dan kelayakan fasilitas yang ramah difabel. Pemerintah sebagai penyedia layanan utama harus mampu memenuhi hak yang sama bagi difabel. Pada hakekatnya pelayanan publik merupakan tugas utama dalam administrasi Negara yang dilakukan oleh Aparatur
Negara. Perkembangan yang muncul di sejumlah negera dalam bidang pelayanan publik menunjukkan adanya pergeseran lebih ke arah penerapan prinsip orientasi pasar dalam penyediaan pelayanan (Osborn dan Gaebler, 1999). Ini berarti bahwa pelayanan yang diberikan pemerintah harus mengutamakan pelayanan terhadap 
masyarakatnya. Hal ini diperkutat dengan prinsip catalytic government, yang mengandung arti bahwa aparatur pemerintah dalam memberikan pelayanan publik bertindak sebagai katalisator, memberikan kemudahan dan kelancaran. Untuk itu dibutuhkan visi yang jelas dalam memebrikan pelayanan yang terdepan untuk masyarakatnya.

\section{METODE PENELITIAN}

Metode penelitian kemampuan "Aksesbilitas Penyandang Disabilitas dalam Pelayanan Publik di Kabupaten Tegal" menggunakan metode penelitian kualitatif. Penggunaan data kualitatif yaitu Forum Group Discussion (FGD) dari responden, observasi di lingkungan responden tinggal dan kajian dokumen yang sesuai dengan data yang dibutuhkan. Populasi adalah sekelompok individu yang memliki karakteristik yang sesuai dengan variabel penelitian. Dari penelitian "Aksesbilitas Penyandang Disabilitas dalam Pelayanan Publik di Kabupaten Tegal" dapat diambil populasi 'semua difabel di Kabupaten Tegal'. Sampel yaitu sebagian kecil dari populasi. Teknik sampling adalah random sampling yaitu pengambilan sampel secara acak. Penulis bebas menentukan cara teknik sampling dengan mempertimbangkan kondisi dari subyek penelitian. Dalam pengambilan sampel random maka dari populasi 'semua penyandang disabilitas di
Kabupaten Tegal' diambil sampelnya yaitu kategori difabel laki-laki, perempuan, kusta dan psikososial yang berjumlah 30 orang.

Analisis data menggunakan triangualsi data yaitu dengan Forum Group Discussion (FGD) dari responden dengan tim peneliti yaitu berupa wawancara kepada responden. Observasi lingkungan responden yaitu di tempat responden tinggal maupun bekerja. Observasi secara luas dilakukan pada sampel wilayah di Kabupaten Tegal yaitu pada 10 Kecamatan yaitu pada Kecamatan Slawi, Adiwerna, Jatinegara, Warureja, Kramat, Kedungbanteng, Pangkah, Bumijawa, Bojong, dan Margasari. Wilayah yang menjadi sampel dalam penelitian merupakan wilayah yang memiliki akses fasilitas publik yang bervariasi yaitu dari wilayah kota sampai ke pedesaan. Rentang wilayah sampel merupakan variasi demografi yang ada di Kabupaten Tegal yaitu daerah pesisir pantai sampai pada daerah pegunungan.

Kaijan data yang diperoleh peneliti berupa dokumen-dokumen dari pendataan Difabel Slawi Mandiri yang telah dilakukan oleh anggota DSM. Pendataan yang dilakukan merupakan kegiatan dari difabel untuk difabel. Dari hasil pendataan tersebut menjadi dasar peneliti untuk analisis data menggunakan triangulasi sumber untuk memadukan data yang diperoleh dari wawancara dan observasi. Berdasarkan data pendataan difabel LBK-DSM Kabupaten Tegal tahun 2015 jumlah difabel ada 134 jiwa. Ini merupakan data dari sampel yang 
terdiri dari dua desa yaitu Desa Grobog dan Bogares di Kabupaten Tegal. Akan bertambah jumlah tersebut jika ada pendataan total di seluruh wilayah kecamatan di Kabupaten Tegal. Dari jumlah difabel tersebut memiliki rentang usia dari 0 tahun - usia tua.

\section{HASIL DAN PEMBAHASAN}

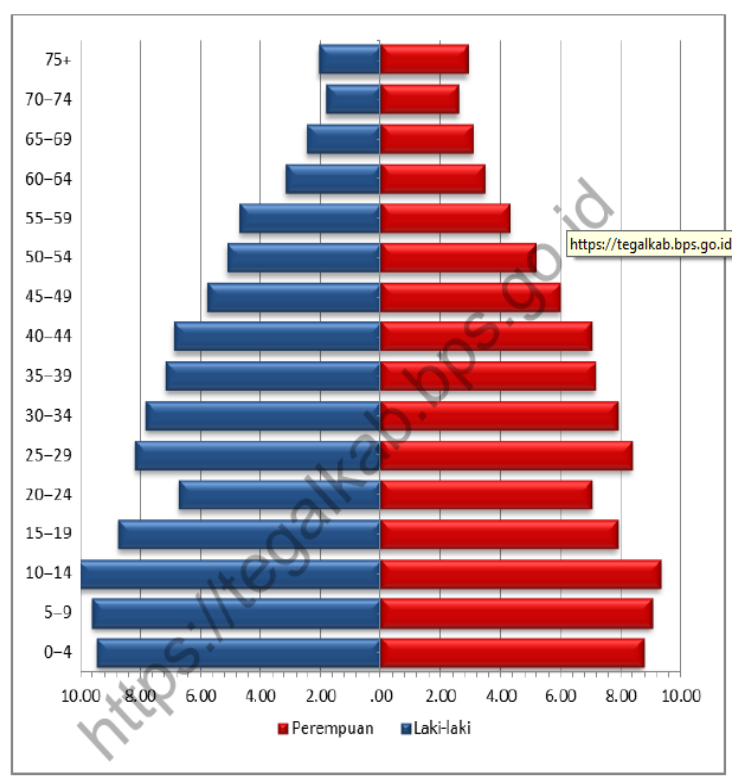

Gambar 5.4 Piramida Penduduk Kabupaten

Tegal 2015

Menurut gambar piramida penduduk di atas maka dapat dijelaskan bahwa jumlah penduduk usia muda lebih banyak dibandingkan usia tua baik laki-laki dan perempuan. Penduduk usia dari 0 - 4 sampai pada usia 30 - 34 mendominasi di Kabupaten Tegal. Begitu pula dengan jumlah populasi usia muda Kabupaten Tegal di dalamnya terdapat populasi disabilitas yang menyebar di beberapa kecamatan. Hal ini berarti bahwa banyaknya populasi penduduk berada di usia muda yaitu usia dalam kondisi produktif yang dapat menggunakan segenap daya pikir dan fisik untuk keberlangsungan hidupnya.

Jumlah Pencari Kerja Terdaftar di Kabupaten Tegal Pada Dinas Sosial Tenaga Kerja dan Transmigrasi Kabupaten Tegal pada Tahun 2015 sebesar 11.836 pekerja terdiri dari 6.444 laki-laki dan 5.392 perempuan. Proporsi terbesar pencari kerja yang mendaftar pada dinas Sosial dan Tenaga Kerja berpendidikan terakhir SMK yaitu sebesar 42,15 persen (4.989 pekerja). Berdasarkan hasil survei yang dilaksanakan Badan Pusat Statistik Kabupaten Tegal, angkatan kerja di Kabupaten Tegal tahun 2015 mencapai 629.471 orang, dengan Tingkat Partisipasi Angkatan Kerja (TPAK) sebesar 60,91 persen, Tingkat Pengangguran Terbuka (TPT) sebesar 9,52 persen.

Jumlah penduduk berumur 15 tahun ke atas menurut jenis kegiatan selama seminggu dan jenis kelamin tahun 2015 terbagi menjadi dua yaitu: (1) Angkatan kerja yaitu penduduk yang bekerja sejumlah 629.471 jiwa dan penangguran terbuka 59.805 jiwa. (2) Bukan angkatan kerja yang terbagi menjadi tiga kegiatan yaitu populasi yang bersekolah sejumlah 81.873 jiwa, mengurus rumah 263.668 jiwa dan lainnya 58.374. Dalam jumlah tersebut terdapat populasi difabel di dalamnya. Dalam

Pada bidang pendidikan difabel yang menempuh sekolah formal tetapi tidak menamatkan pendidikannya, seperti tidak lulus SD/SR. 
Tabel 5.5

Data difabel bidang pendidikan

\begin{tabular}{llc}
\hline No & \multicolumn{1}{c}{ Jenjang } & Jumlah \\
\hline 1 & SD & 73 \\
2 & SMP & 24 \\
3 & SMA/SMK & 16 \\
4 & Diploma I/III & 3 \\
\hline
\end{tabular}

Fasilitas di sekolah umumnya standar yang tidak diperuntukkan bagi difabel. Hanya beberapa sekolah seperti SLB Negeri/Swasta yang memiliki lingkungan yang ramah difabel. Dari aspek fisik (jalan, halaman, koridor, ruang kelas dan area bermain) memberikan ruang yang memadai bagi difabel untuk mengembangkan diri. Namun perlu diawasi siswa yang berada di luar kompleks sekolah karena sekolah yang berada di depan jalan raya.

Pada bidang kesehatan yang merupakan aspek penting di kehidupan setiap manusia tidak terkecuali difabel. Setiap orang pasti pernah merasakan sakit begitupula difabel. Sakit yang dialami difabel bisa terjadi selain dari kondisi fisiknya. Maka perlu adanya penanganan kesehatan bagi difabel. Hasil observasi dari beberapa tempat kesehatan yaitu rumah sakit negeri dan swasta di Kabupaten Tegal dapat dilihat dari fasilitas fisiknya. Jalur jalan yang dibuat di rumah sakit sudah ramah difabel karena memang dikondisikan bagi keadaan pasien. Fasilitas fisik sudah memadai bagi keberadaan difabel. Namun dari segi pelayanan publik yang masih perlu adanya peningkatan. Seperti pada meja resepsionis di rumah sakit yang letaknya terlalu tinggi sehingga sulit bagi beberapa difabel untuk dapat berinteraksi dengan pertugas kesehatan di tempat tersebut.

Kondisi kesejahteraan berarti bahwa masyarakat dapat dengan mudah mengakses tempat-tempat umum yang menjadi kegiatan sehar-harinya. Pasar adalah salah satunya. Bagi masyarakat keberadaan pasar (tradisional maupun modern/swalayan) sangat diperlukan sebagai tempat berlangsungnya kegiatan ekonomi. Baik itu sebagai pelaku ekonomi (penjual) maupun konsumen (pembeli).

Fasilitas publik yang tersedia seperti transportasi umum sudah menjangkau sampai di depan komplek pasar. Angkutan umum yang tersedia dari kendaraan besar seperti bis elf, angkutan desa (bak terbuka), angkutan kota, becak dan delman menjadi sarana yang menunjang bagi masyarakat. Sarana fisik dari pasar seperti jalur khusus difabel tidak ada. Respon masyarakat di pasar terhadap keberadaan difabel tidak baik. Seperti pedagang difabel menjual sayuran dihargai sangat rendah oleh pembeli, padahal sayuran yang dijual sama kualitasnya dengan pedagang lain. Hal ini masih menjadi pekerjaan rumah untuk dapat mengubah persepsi masyarakat terhadap keberadaan difabel.

Kegiatan warga yang umumnya dilakukan di lingkungan tempat tinggalnya seperti pengajian, pementasan dan kegiatan besar nasional dan hari raya. Masyarakat yang sudah tahu tentang keberadaan difabel 
di lingkungan tempat tinggalnya memiliki persepsi yang berbeda-beda.

Kegiatan masyarakat akan lebih bermakna jika ditunjang oleh fasilitas yang mamadai. Partisipasi masyarakat sangat antusias jika ada kegiatan pengajian yang diselenggarakan dalam rangka hari besar. Warga berbondong-bondong hadir bahkan dari luar daerah untuk menyaksikan. Masjidmasjid di Kabupaten Tegal memiliki ruang yang cukup ramah difabel. Akan sangat terlihat pada tempat wudlu yang bisa dijangkau difabel atau tidak. Petugas masjid (takmir) yang ada di masjid perlu memperhatikan jamaahnya khususnya difabel untuk bisa beribadah dengan baik.

Ruang partai politik bagi masyarakat sangat penting bagi kehidupan berbangsa dan bernegara. Indonesia adalah negara demokrasi yang memiliki periode pemilihan pemimpin. Bagi masyarakat pemilihan umum adalah agenda besar pesta demokrasi yang dilakukan dengan antusiasme yang tinggi. Masyarakat bebas untuk memilih siapa saja yang dianggap layak untuk menjadi pemimpin. Begitu pula dengan difabel yang memiliki kebutuhan khusus saat pemilihan umum. Ada beberapa petugas TPS (Tempat Pemungutan Suara) yang mendatangi warga difabel untuk dapat menggunakan hak suaranya. Namun memang masih banyak petugas TPS yang tidak melakukan hal tersebut.

\section{KESIMPULAN DAN SARAN}

Hasil analisis data menunjukkan hal yang signifikan antara aksesbilitas penyandang disabilitas dalam pelayanan publik di Kabupaten Tegal. Faktor-faktor yang memperkuat adanya korelasi yang signifikan antara antara aksesbilitas penyandang disabilitas dalam pelayanan publik di Kabupaten Tegal adalah keterlibatan masyarakat dan keluarga bagi difabel. Layanan ramah difabel ada pada lima bidang, yaitu: (1) bidang ekonomi, (2) bidang kesehatan, (3) bidang pendidikan, (4) bidang budaya (keagamaan), dan (5) bidang politik.

Saran yang dapat diberikan antara lain keluarga memberikan dukungan bagi difabel sebagai orang terdekat yang dapat membantu difabel dalam mengakses layanan publik. Masyarakat mendukung dan mendorong difabel dalam bersosisalisasi di lingkungan tempat tinggalnya. Khususnya dalam informasi pendataan yang diselenggarakan pemerintah. Pemerintah memberikan fasilitas layanan publik bagi difabel khususnya yang sama sekali tidak terjangkau bagi difabel.

\section{DAFTAR PUSTAKA}

Australian Aid. 2016. Briefing Note Indonesia Infrastructure Initiative.

Arikunto, Suharsimi. 2013. Prosedur Penelitian: Suatu Pendekatan Praktik. Jakarta: Rineka Cipta.

Azwar, Saifuddin. 2014. Penyusunan Skala Psikologi. Pustaka Pelajar: Yogyakarta.

BPS Kabupaten Tegal. 2015. Diunduh pada $(22,12,16)$, https://tegalkab.bps.go.id 
International Labour Organization. 2015. Inklusi Penyandang Disabilitas Muda: Kasus Bisnis. Organisasi Perburuhan Internasional: Jakarta.

Kabupaten Tegal dalam Angka 2016. Katalog: 1102001.3328. CV. Romo Tegal: BPS Kabupaten Tegal

LBK-DSM Kabupaten Tegal. Laporan Pendataan Difabel Desa Bogares Kidul Revisi Tahun 2015.

LBK-DSM Kabupaten Tegal. Laporan Pendataan Difabel Desa Grobog Kulon Revisi Tahun 2015.

Myres, David G. 2012. Psikologi Sosial Ed 10 Buku 2. Jakarta: Salemba Humanika.

Osborn, D and Ted Gabler, 1999, Reiventing Government : How the Entrepreneurial Spirit is Transforming the Public Sector.

PP Nomor 43 tahun 1998 tentang Upaya Peningkatan Kesejahteraan Sosial Penyandang Cacat

Sugiyono. 2014. Metode Penelitian Pendidikan Pendekatan Kuantitatif, Kualitatif dan $R \& D$. Alfabeta: Bandung.

Sugiono dkk. 2014. Indonesian Journal of Disability Studies. Klasterisasi Mahasiswa Difabel Indonesia berdasarkan Backgruound Histories dan Studying Performance. Volume 1 Issues 1 pp 20-26.

UU Nomor 4 Tahun 1997 tentang Penyandang Cacat

UU Nomor 8 Tahun 2016 Tentang Penyandang Disabilitas

Zeithaml, Valeria, Parasuraman and Leonard Berry, 1990, "Delivering Quality Service", Balancing Customer Perceptions and Expectation, New York, The Free Press. 